\title{
El espejismo de los lugares. La construcción del espacio en el desierto tarapaqueño. Huara, siglos XIX-XX ${ }^{1}$
}

\author{
Claudio Aguirre Munizaga² y Alberto Díaz Araya ${ }^{3}$
}

\begin{abstract}
RESUMEN
Este artículo discute los formatos socioculturales e históricos de construcción de los espacios en el poblado de Huara, en la provincia del Tamarugal, Región de Tarapacá. El objetivo es analizar, desde las disciplinas de la historia, la antropología y la geografía cultural, cómo el espacio y los lugares públicos y privados han generado una impronta cultural que caracteriza a esta localidad del desierto de Atacama, para diferenciarlas de otros asentamientos humanos en una serie de contextos históricos que arrancan con el ciclo salitrero, para posteriormente reconfigurarse en un sitio aledaño a la carretera Panamericana Norte.
\end{abstract}

Palabras clave: Huara, espacios, lugares, desierto, identidad.

\section{ABSTRACT}

This article discusses the sociocultural and historical forms of the construction of spaces in the town of Huara in the province of Tamarugal Tarapacá Region. The aim is to analyze from the disciplines of history, anthropology and cultural geography such as space and public and private places have created a cultural imprint that characterizes this region of the Atacama Desert, to differentiate them from other human settlements in a series of historical contexts that iniciate the saltpetre cycle, then reconfigured into a site adjacent to the North Panamerican Highway.

Key words: Huara, spaces, places, desert, identity.

"Los lugares son historias plegadas y fragmentadas, de pasados robados a una legibilidad otra, tiempo amontonado que se puede desatar, pero que está allí, como relatos a la espera que resisten el estado de desecho, como una simbolización enquistada en el dolor o el placer del cuerpo" (De Certeau, 1990: 163).
Este trabajo, con cierta sonoridad de ensayo, intenta reflexionar sobre la construcción del espacio que se elaboró en la desértica pampa. No es un recuento histórico, ni tampoco pretende ser una etnografía de la vida en las salitreras. Interesa dar cuenta de que ciertos asentamientos humanos operaron no solo en el formato industrial durante el ciclo salitrero, sino que al mismo tiempo permitieron articular una serie de vínculos y

1 Artículo recibido el 3 de septiembre de 2008 y aceptado el 27 de abril de 2009.

2 Instituto de Investigaciones Arqueológicas y Museo R. P. Gustavo Le Paige, Universidad Católica del Norte (Chile). E-mail: claudio.aguirre@ucn.cl

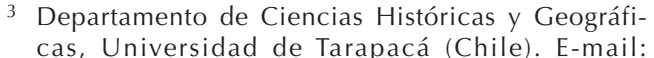
albertodiaz@uta.cl 
redes sociales entre la pampa y los valles tarapaqueños, siendo en tal sentido el poblado de Huara un nodo que redireccionó las actividades regionales, permitiendo fluir espacios locales que se reconfiguraron en diferentes ejes, siguiendo siempre el ritmo de los contextos históricos que vivenciaron, sobre todo hacia la segunda mitad del siglo $\mathrm{XX}^{4}$.

\section{Los inicios de la comunidad}

El origen de Huara es incierto en cuanto a una fecha precisa de su fundación, al igual que Iquique, Tarapacá o Pisagua, lugares que no precisan su partida fundacional (Díaz, 2007; Donoso, 2003). Pero este obstáculo vinculado al dato descriptivo no puede impedir levantar algunas hipótesis. El análisis de mapas coloniales y republicanos, puntualmente del periodo peruano (18211883), no arroja ni ilustra algún tipo de asentamiento localizado en la pampa adyacente al oriente de la cordillera de la costa tarapaqueña donde hoy se erige Huara. Asimismo, no existen referencias documentales sobre lugares que se encuentren distribuidos en la gradiente occidental altiplano-precordillera-quebradas-pampa-litoral, o que registren tambos, posadas, paskanas, pukara u otro sitio con una posible data precolombina, vinculando a este circuito a un antiguo recinto en el perímetro de Huara.

\footnotetext{
4 El poblado de Huara se localiza $75 \mathrm{~km}$ al noreste del puerto de Iquique, en la depresión intermedia del Norte Grande de Chile, entidad geográfica reconocida localmente como la pampa del Tamarugal, debido a antiguos bosques de prosopis que existieron en la zona (algarrobos y tamarugos). El terremoto del 13 de junio del año 2005 dañó notoriamente la infraestructura del pueblo, siendo uno de los sitios más azotados por este evento telúrico que diezmó al norte chileno. A partir de aquel año, diferentes discursos tanto de autoridades locales como de entidades estatales hicieron referencia hacia el valor patrimonial del lugar y a una serie de propuestas reconstructivas. A la fecha aún no se ha materializado ningún proyecto habitacional, ni estudios sistemáticos sobre el patrimonio material de este pueblo y otras localidades de la precordillera tarapaqueña. Como nota aparte, se debe agradecer al licenciado en Historia Paulo Lanas Castillo por su aporte en la revisión, ordenamiento y comentarios del material bibliográfico aquí expuesto.
}

Como es sabido, en el plano de Antonio O’Brien (1765) no se menciona a Huara, solo existen referencias generales sobre un camino que baja de la quebrada de Tarapacá llamado Cataumano y otro sendero ubicado al sur denominado camino de Cruz de Piedra (O’Brien, 1765; Bermúdez, 1975; Núñez, 1989). Estas rutas solo describen parcialmente sectores adyacentes a lo que hoy es Huara, lo que presumiblemente podría constituir un sitio eriazo inhabitado donde se desprendían caminos troperos y senderos que disectaban la llanura salitrosa de la pampa del Tamarugal.

En los mapas del siglo XIX de Carey y Mathew en 1814, Carey en 1822, Colton en 1856, Bollaert \& Smtih en 1851 y Beltrand en 1979 no se identifica un asentamiento o un sitio de descanso, tambo o aguada en el área de Huara. Solamente en el mapa y perfil topográfico de Bollaert \& Smtih del año 1851 se advierte un promontorio que recibe la denominación de Huara, localizado en las serranías contiguas a la actual localidad, posiblemente en el cerro donde hoy se ubican las antenas de comunicación radial y televisión (Silva, 1977). Ahí podría encontrarse la relación denominativa con Huara.

El vínculo nominativo con una entidad geográfica cercana parece ser la apuesta más plausible que fundamenta la relación identitaria entre paisaje y sociedad, la cual, desde la perspectiva de la geografía cultural, supone la construcción del medio ambiente a imagen y semejanza de los grupos humanos que inciden en el entorno natural, transformándolo en un paisaje cultural (Díaz y Mondaca, 1999).

Pensar que Huara podría estar correlacionada con un sistema de postas precolombinas sin evidencias parece una hipótesis prematura, carente de antecedentes que justifiquen dichas aseveraciones. En suma, creemos que la alternativa va por redireccionar la discusión hacia épocas tardías, principalmente al periodo salitrero (18801930), sosteniendo que la antigüedad no supone necesariamente valoración patrimonial, sino que son los vestigios que dan cuenta de manifestaciones sociales complejas los que deben valorarse de acuerdo a los contextos y significancias comunitarias, 
y no restringir el argumento a la mera temporalidad de las ruinas.

Teóricamente, no es satisfactorio el argumento que busca lo milenario, lo remoto, lo pretérito como factor fundante de una aparente riqueza histórica de una localidad, aldea o barrio, como discurso ideológico, identitario o étnico en una cierta plataforma de una matriz cultural como puede advertirse en algunos estudios esencialistas (Chipana, 1996; Van Kessel, 1992; Larraín, 1987); o también como empresa o una política manipuladora del pasado con fines de mercado o de piezas museográficas o patrimoniales, tal como ha problematizado en profundidad Pablo Aravena en sus análisis en torno al puerto de Valparaíso y su denominación como patrimonio de la Humanidad (Aravena, 2003; Aravena et al., 2006).

Se entiende que no existe problema en valorar los edificios y las prácticas sociales que poseen una corta temporalidad, y que dan cuenta de una dinámica red social, forjadora de sistemas de vidas particularizados en zonas desérticas como es el norte chileno. Lo relevante de aquel supuesto lo constituyen las formas de vida o habitus ${ }^{5}$ elaborados por los hombres y mujeres que hace un poco más de 100 años reinventaron la tradición en el desierto, identificándose bajo la categoría social de pampinos, amén de una multiplicidad de sujetos y de culturas que articularon durante la época salitrera (González, 2002a; González, 2002b).

Por ahora, se conjetura que Huara está directamente vinculada al auge del ciclo salitrero, principalmente bajo la presencia de la administración chilena tras la Guerra del Pacífico (1879-1883). El factor que gatilla el asentamiento en el poblado de Huara lo constituye la construcción de la línea férrea. Dicha red ferroviaria, que se extendía por la

\footnotetext{
5 Para Pierre Bourdieu el habitus "es lo que se ha adquirido, pero que se ha encarnado de forma duradera en el cuerpo en forma de disposiciones permanentes. La noción recuerda así constantemente que se refiera a algo histórico, que está vinculado a la historia individual, y que se inscribe en un modo de pensamiento genético, en oposición a modos de pensamientos esencialistas" (Bourdieu, 2000: 133).
}

pampa colindante con la cordillera costera, permitió intercomunicar a todas las oficinas y paradas salitreras en una multidireccionalidad de puntos, generando un epicentro donde confluían (y también partían) diversas rutas, tanto de zonas bajas (vías costeras o de calicheras ubicadas al interior de las serranías costeñas) como de sitios dispersos en la pampa o alrededores.

Es ahí donde se levanta espontáneamente Huara, al lado del camino; o mejor dicho: adosado a la línea del ferrocarril. Dicho pueblo debía acoger a los trabajadores en infinidad de servicios, así como desplegar la burocracia pública y atraer al comercio privado, permitiendo que funcionara un sistema nodal de intercomunicación bajo la lógica industrial.

\section{Huara, desierto y ferrocarril}

Volviendo a la temporalidad fundacional, tentativamente es probable que Huara surgiera hacia fines del periodo republicano peruano (1877-1880) como un asentamiento precario de cateadores o arrieros, incitado por el boom industrial salitrero que eclosiona neurálgicamente la vida en el desierto. Pero el punto de inflexión lo constituye el día 31 de octubre de 1884, fecha en la cual, por decreto de Ley $N^{\circ} 2.261$, se crea la provincia de Tarapacá, inaugurando una estructura política y limítrofe que asegurara la presencia del Estado nación chileno en los nuevos territorios conquistados. A saber, la provincia de Tarapacá se dividió en dos departamentos denominados Pisagua y Tarapacá, además de subdelegaciones y distritos. En tal orden administrativo, la localidad de Huara pasa ahora a formar parte del territorio chileno como un poblado con reconocimiento estatal y una estructura departamental particular (Cuadro $\mathrm{N}^{\circ} 1$ ).

Bajo este formato burocrático, Huara formaliza su asentamiento para dar vida a diferentes actividades que permitían la interacción de diferentes individuos y grupos que trabajaban en los cantones salitreros. Es lógico argumentar que existiendo varias calicheras y paradas diseminadas en la pampa, entonces es dable contar con un nodo que las abasteciera, ya sea en víveres, en servicios públicos (co- 
rreos, telégrafos, registro civil), así como en espacios lúdicos dedicados a la compra-venta de productos y también a la diversión.

Para fines de la década de 1880, Francisco Riso Patrón describía que Huara era un "pueblo nuevo, a orillas de la línea férrea, en donde se ha formado una población, ve- cina al paradero o estación de ferrocarril, está en el cantón de su nombre; departamento y provincia de Tarapacá. Huara es el tercer distrito de la $7^{a}$ subdelegación de Pozo Almonte y tiene en el cantón de su nombre las oficinas salitreras más valiosas en explotación (las de su contorno) denominadas: Ramírez, Constancia, Santa Rosa, Ro-

Cuadro $\mathrm{N}^{\circ} 1$

Departamento de Tarapacá, subdivisión administrativa, 1884

\begin{tabular}{|c|c|}
\hline Subdelegación & Distritos \\
\hline Subdelegación Nº 1 & Distrito $N^{\circ} 1$ Hospital \\
\hline Urbana Iquique & Distrito $N^{\circ} 2$ Parroquia \\
\hline Subdelegación $N^{\circ} 2$ & Distrito $N^{0} 1$ La Puntilla \\
\hline Urbana de la Aduana & Distrito $N^{\circ} 2$ del Muelle \\
\hline Subdelegación $N^{\circ} 3$ & Distrito $N^{\circ} 1$ Plaza Montt \\
\hline Urbana de la Escuela & Distrito Nº 2 Plaza Condell \\
\hline Subdelegación No 4 & Distrito $N^{\circ} 1$ Cárcel \\
\hline Urbana de la Avenida Cavancha & Distrito $N^{\circ} 2$ Morro \\
\hline Subdelegación Nº 5 & Distrito $N^{\circ} 1$ Mineral \\
\hline Huantajaya (rural) & Distrito $N^{\circ} 2$ Santa Rosa \\
\hline Subdelegación Nº 6 & Distrito $N^{\circ} 1$ Caleta \\
\hline Caleta Buena (rural) & Distrito $\mathrm{N}^{\circ} 2$ Alto \\
\hline Subdelegación Nº 7 & Distrito $N^{\circ} 1$ La Tirana \\
\hline Pozo Almonte (rural) & $\begin{array}{l}\text { Distrito } N^{\circ} 2 \text { del Pueblo (Pozo) } \\
\text { Distrito } N^{\circ} 3 \text { Huara }\end{array}$ \\
\hline Subdelegación $N^{\circ} 8$ & Distrito $N^{\circ} 1$ Yungay \\
\hline La Noria (rural) & $\begin{array}{l}\text { Distrito } N^{\circ} 2 \text { Cocina } \\
\text { Distrito } N^{\circ} 3 \text { Soledad }\end{array}$ \\
\hline Subdelegación Nº 9 & Distrito $N^{\circ} 1$ Patillos \\
\hline Salitreras del Sur (rural) & Distrito $N^{\circ} 2$ Pampa \\
\hline Subdelegación Nº 10 & Distrito № 1 Pabellón \\
\hline Guaneras (rural) & Distrito $N^{\circ} 2$ Guanillos \\
\hline Subdelegación Nº 11 & Distrito No 1 Quebrada Tarapacá \\
\hline \multirow[t]{5}{*}{ Tarapacá (rural) } & Distrito $N^{\circ} 2$ Mocha \\
\hline & Distrito $N^{\circ} 3$ Sibaya \\
\hline & Distrito $N^{\circ} 4$ Cariquima \\
\hline & Distrito $N^{\circ} 5$ Sotoca \\
\hline & Distrito $N^{\circ} 6$ Mamiña \\
\hline Subdelegación Nº 12 & Distrito $N^{0} 1$ Matilla \\
\hline Pica (rural) & Distrito $N^{\circ} 2$ Canchones \\
\hline Subdelegación № 13 & Distrito $N^{\circ} 1$ Cerro Gordo \\
\hline Challacollo (rural) & Distrito $N^{\circ} 2$ Guatacondo \\
\hline
\end{tabular}

Fuente: Silva, 1913. 
sario de Huara, San Jorge, Tres Marías y Primitiva. Este pueblo está llamado a prosperar rápidamente, por tener en sus alrededores las oficinas más valiosas de la Pampa, así como la mayor población que tienen las mencionadas oficinas, que no baja de 6.000 habitantes" (Riso Patrón, 1890: 74).

Tal como lo expresa Riso Patrón (1890), Huara se despliega tempranamente como un nodo articulador en la pampa tarapaqueña, cobijando a distintas oficinas que se encontraban a sus alrededores, insertándolas en la estructura política, comunicacional y comercial. Para dicho efecto se organizó el cantón de Huara. De acuerdo con González (1991), los cantones salitreros eran divisiones geográficas de los terrenos salitrales que estaban vinculados a un mismo puerto de embarque; por tanto, las oficinas (Figura $N^{\circ} 1$ ) que en ellos emergían tenían una identidad territorial común. Generalmente se ubicaba un pueblo en medio del cantón, asignándoles el nombre. Los cantones salitreros para fines del siglo XIX eran el de Zapiga, Sal de Obispo, Pampa Negra, San Francisco, Ne-

Figura $N^{0} 1$

Oficinas salitreras de Tarapacá

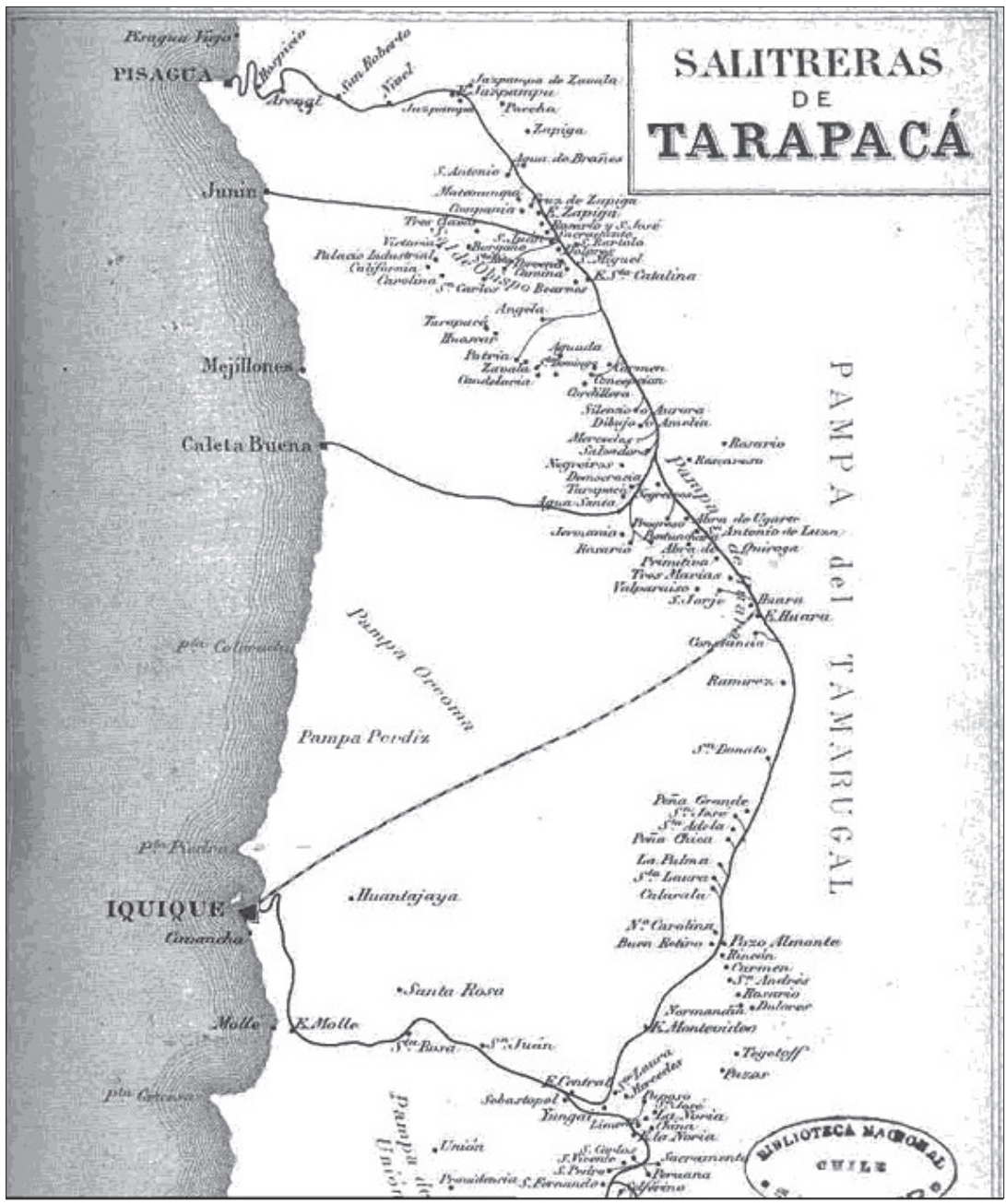

Fuente: Espinoza, 1897. 
greiros, La Peña, San Antonio, Yungay, La Noria, Cocina y Nueva Soledad. Bajo estos parámetros, los cantones en definitiva son entidades geográficas que permiten organizar la actividad industrial, pero también es necesario agregar, de acuerdo a propias reflexiones, que los cantones al unísono, son entidades culturales que permiten generar redes sociales, prácticas locales diversas e identidades colectivas, constituyéndose como un "cantón cultural".

El cantón de Huara ${ }^{6}$, y el pueblo central que estimula este artículo, como estación de ferrocarril paulatinamente comenzó a trans-

6 El cantón de Huara, de acuerdo a Silva (1913), tenía bajo su administración las siguientes oficinas salitreras:

- Constancia: oficina de la compañía salitrera Constancia, representada por Gildemeister y Cía., con domicilio en Iquique; embarca por Caleta Buena. Administrador, don E. Von Schmeling; ingeniero, señor Fritz Weinert; contador, don J. Eduardo V. Wood; fichero, don Manuel Villena Castro; pasatiempo, señor Walter Krais; bodeguero, don Manuel Torres A.; ensayador, don Rodulfo Matis; corrector, don Leonidas Noumenn; jefe de máquina, don Fidel Gálvez; jefe de maestranza, don Liborio Alday. La pulpería era arrendada a don Julián Pérez Herreros.

- Maroussia: oficina de Peretti, Jeffery y Cía., representados por ellos mismos, con domicilio y gerencia en Iquique; embarcan por Caleta Buena. Administrador, don Antonio B. Vernal R.; contador, don Rogelio Gensollen; pasatiempo, don Arturo Merami; bodeguero, don Elías Cáceres; apuntador, don Juan Ossa Ossa; jefe de pulpería, don Juan Brusacá.

- Mapocho: oficina de la The Liverpool Nitrate $\mathrm{C}^{\circ}$ Ltda., representada por Lockett BROS y Cía., con domicilio y gerencia en Iquique; embarca por este puerto. Administrador, don A. H. Hoey; contador y cajero, don E. Jefferson; pasatiempo, fichero y bodeguero, don M. Quiroga A.; ingeniero, don C. Damon; jefe de pulpería, don Benito Casas B.; pulpero. Don Emilio Borrás; corrector, don Mariano Cevallos; jefe de maestranza, don Adrián Barrios; jefe de máquinas, don Lucindo Díaz. Médico de la oficina, doctor Gordon Fowler. Estacamento: 38 estacas peruanas.

- Puntilla de Huara: oficina de la The Rosario Nitrate $\mathrm{C}^{\circ} \mathrm{Ltda}$., representada por Gildemeister y Cía., con domicilio en Iquique; embarca por Caleta Buena. Administrador, don Guillermo Schroder; contador y cajero, don Eduardo Romero; fichero y pasatiempo, don Godofredo Vidal H.; bodeguero, don Santiago Zavala; jefe de pulpería, don Antonio Petric; pulpero, don Simón Jiménez; jefe de pampa, don Ladislao Vernal; ingeniero, don Matías Véliz; jefe de elaboración, don Anuario Órdenes. Médico de la oficina, doctor don Arturo Araos La- formarse en un pueblo y estación obligada para quienes venían desde Negreiros por el norte, Pozo Almonte por el sur, Iquique por el poniente y de los pueblos de las quebradas de Aroma y Tarapacá, además del altiplano andino.

Todas estas oficinas hicieron prosperar a este pueblo y fueron delimitando su planta urbana siempre en torno a la actividad salitrera. Entrado el siglo XX, como bien lo indica Sergio González (1991), importantes negocios se instalaron en Huara, además de venir de distintas nacionalidades (asiáticos, yugoslavos, italianos, peruanos, bolivianos,

rraín, que hace sus visitas los días lunes, miércoles y viernes. La máquina tiene 12 cachuchos de 30 pies de largo por 8 y por 7 , cinco calderos por 28 pies de largo por 8 de diámetro, 5 acendraderas y 2 ascensores para el caliche y el ripio. Se usa únicamente petróleo y el agua para todo el consumo la da un pozo de la pampa servido por tracción eléctrica de la oficina Rosario de Huara.

- Ramírez: oficina de la The Liverpool Nitrate C ${ }^{\circ}$ Ltda., representada por Lockett BROS y Cía., con domicilio en Iquique; embarca por este puerto. Administrador, don R. T. Love; contador, don E. Fergusson; bodeguero, don A. Meléndez; pasatiempo, don A. Watkins; fichero, don E. Saill; jefe de pulpería, don E. de Castro; corrector, don $M$ Zamorano; jefe de maestranza, don R. Ríos; jefe de máquina, don F. Durán.

- Rosario de Huara: oficina de la The Rosario Nitrate $\mathrm{C}^{\mathrm{o}}$ Ltda., representada por Gildemeister y Cía., con domicilio en Iquique; embarca por Caleta Buena. Administrador, don T. Farquharson; contador, don A. E. Nutter; pasatiempo, don V. Lema; bodeguero, don G. E. Malcolm; fichero, don J. Arredondo; jefe de pulpería, don Juan Petric. La máquina tiene 18 cachuchos, 7 calderos y 143 bateas. Estacamento: 260 estacas peruanas.

- Santa Rosa: oficina de don Jorge Jeffery, representada por él mismo, con domicilio y gerencia en Iquique; embarca por este puerto. Administrador, don Juan Hernández; contador, don H. B. Comber; pasatiempo y cajero, don Carlos Arce C.; bodeguero, don Carlos Rosas; fichero, don Luis Bradanovich; jefe de maestranza, don Santiago Macbride; corrector, don César Angulo; jefe de máquinas, don J. F. Lecaros. Estacamento: 964 estacas peruanas.

- San Jorge: oficina de Moldes, Gajo y Cía., representada por ellos mismo, con domicilio en Iquique; embarcan por Caleta Buena. Administrador, don Francisco de A. Camino; contador, don Horacio Fernández; fichero, don Cayetano Alvarellos; bodeguero don Atilano Beltrán; químico, don Maximino Pizarro; jefe de pulpería, don Arturo Sanjurjo; pulperos, señores Gaspar Lamas y José Viña; corrector, don Froilán Ayala; jefe de maestranza, don Abelardo González; jefe de máquinas, 
entre otros), para dedicar su vida al comercio: corresponsales de prensa, botica, panaderías, lavanderías, carnicería, restoranes, matadero, salas de diversión y un cementerio de los más grandes de la pampa.

Sobre el ferrocarril, se puede agregar que con el estallido de la guerra de 1879 los cambios que experimentó el casi monopolio de los Hermanos Montero sobre los ferrocarriles de Tarapacá fueron determinantes. La deuda que contrajo la compañía Montero Hermanos obligó a estos a perder terreno en el ámbito del transporte férreo. Para el año 1891 esta firma solo registraba una ruta poco rentable, como era la que unía Patillos por la costa con Lagunas en casi el extremo sur de la ahora provincia chilena de Tarapacá (Blakemore, 1977).

En 1882 se organizó la sociedad inglesa The Nitrate Railway Company Limited, refinanciando mediante un cuarto empréstito los tres anteriores pedidos cuando existían solo los Hermanos Montero; ello significó asentar en sus libros, como pasivo global, $£ 1.950 .000$, mientras declara como capital $£ 1.200 .000$ (Blakemore, 1977). Esta firma comenzó rápidamente a apoderarse del movimiento y transporte vinculado al salitre. Según Blakemore, a principios de 1888 la situación se vuelca a favor de los ingleses al comenzar facturando dividendos cada vez mayores, controlando así la casi totalidad de

don Idelfonso López; boletero, don Leonardo Delgadillo. La máquina tiene 16 cachuchos y 78 bateas. Estacamento: 85 estacas peruanas.

- Santiago: oficina de la The Santiago Nitrate $\mathrm{C}^{\circ}$ Ltda., con domicilio en Iquique; embarca por Caleta Buena. Administrador, don S. P. Lowe; contador, don G. R. Watson; pasatiempo, don C. A. Rigden; bodeguero, don E. A. Colvin; ingeniero, don J. B. Coull; jefe de maestranza, don L. Collins; jefe de máquina, don Arturo Cáceres; jefe de pulpería, don J. Perón. La oficina dispone de 3 motores Diesel de 95 caballos de fuerza cada uno y tres generadores eléctricos de corriente alternada de 220 volts, los cuales dan la fuerza necesaria para mover toda la maquinaria de la oficina. Tiene seis acendraderas con plano inclinado para el acarreo hasta la máquina. Para el transporte de material desde la pampa, cuenta con cuatro locomotoras y setenta y cinco carros Lyons. La casa de Yodo consta de seis bateas y su respectiva retorta. Para el abastecimiento de agua a la oficina, hay un pozo de $84 \mathrm{~m}$ de profundidad, con bombas movidas por fuerza eléctrica, que es transmitida desde la comunicación de trenes en la pampa. La llegada a la sociedad del inglés Thomas North acumula aún más entradas favorables para The Nitrate Railway Company Limited. Solo la compañía de ferrocarriles de Agua Santa, controlada por la firma Campbell, Outram y Cía., podía disputarle cierto sector del monopolio de la empresa integrada por North (Blakemore, 1977).

Las tarifas por el concepto de flete que pagaban algunas de las oficinas salitreras a The Nitrate Railway Company Limited, en peniques por quintal español de carga, se expresan en el Cuadro $\mathrm{N}^{\circ} 2$.

Hacia fines del siglo XIX la circulación de trenes, vagones y carros había aumentado considerablemente en la pampa. En la provincia de Tarapacá ya existían tres líneas férreas. La principal, era la de los ferrocarriles salitreros que unían Iquique con Pisagua y recorría las oficinas salitreras que circundaban el área oriental de la cordillera de la Costa. Esta línea, sin contar diversos ramales que partían para diferentes oficinas inmediatas a la línea principal, recorría de Iquique a Pisagua 124 1/2 millas (Espinoza, 1897). La ruta iba desde de Pisagua a la salitrera Tres Marías (cantón de Huara), que simbolizaba el punto de división entre el departamento de Pisagua y el de Tarapacá, durante este trayecto se visitaban las estaciones indicadas en el Cuadro $N^{\circ} 3$.

la oficina por medio de una corriente de 3.000 volts. Estacamento: 250 estacas peruanas.

- Tres Marías: oficina de Perfetti, Jeffery y Cía., representada por ellos mismos, con domicilio en Iquique; embarca por Caleta Buena. Administrador, don Tomás Hawieson; inspector e ingeniero, don Pilade Ferro; contador, don Ricardo Arce; bodeguero, don Alcides Meriggio; jefe de pulpería, don Juan Catanzaro; jefe de maestranza, don Emilio Catalán; jefe de máquinas, don Cornelio Lecaros.

- Valparaíso: oficina de la Compañía de Salitres y Ferrocarril de Agua Santa, representada por ella misma, con domicilio en Valparaíso y gerencia en Agua Santa; embarcan por Caleta Buena. Administrador, don F. W. Corthorn; cajero, don C. Zavala; pasatiempo, don Juan Narea; pagador, don Jorge Zavala; bodeguero, señor Harry Humberstone; ayudante de bodega, Francisco Clavijo; jefe de pulpería, don Ismael Fernández. Profesor de la escuela de niños, don Juan Pérez, profesora de la escuela de niñas, señora Isolina C. de Pérez. Médico de la oficina, doctor don José Quintana, residente en Agua Santa. 
Cuadro $\mathrm{N}^{\circ} 2$

Tarifa del ferrocarril de Iquique

\begin{tabular}{|c|c|c|}
\hline $\begin{array}{l}\text { Distancia } \\
\text { (millas) }\end{array}$ & $\begin{array}{l}\text { Nombre de } \\
\text { oficinas }\end{array}$ & $\begin{array}{c}\text { Tarifa } \\
\text { (peniques) }\end{array}$ \\
\hline 31,78 & Yungay & 7,74637500 \\
\hline 33,82 & $\begin{array}{l}\text { Santa Beatriz } \\
\text { (Noria) }\end{array}$ & 8,24362500 \\
\hline 36,00 & Paposo & 8,775000 \\
\hline 36,13 & Peruana & 8,80668750 \\
\hline 36,36 & Sacramento & 8,86275000 \\
\hline 37,02 & San Carlos & 9,02362500 \\
\hline 37,45 & San Fernando (1) & “ \\
\hline 40,50 & Argentina & 9,75000 \\
\hline 40,50 & Solferino & “ \\
\hline 40,50 & San Pablo & “ \\
\hline 43,60 & Esmeralda & “ \\
\hline 43,65 & $\begin{array}{l}\text { Serena } \\
\text { (Pozo Almonte) }\end{array}$ & “ \\
\hline 43,65 & Tegethoff & “ \\
\hline 43,65 & Normandía & “ \\
\hline 43,75 & San Juan & “ \\
\hline 44,15 & Buen Retiro & " \\
\hline 46,12 & Cala-Cala & “ \\
\hline 47,00 & San Lorenzo & “ \\
\hline 48,00 & Virginia & “ \\
\hline 48,00 & $\begin{array}{l}\text { Santa Elena } \\
\text { (Virginia) }\end{array}$ & ، \\
\hline 48,06 & La Palma & “ \\
\hline 49,31 & Peña Chica & “ \\
\hline 51,02 & $\begin{array}{l}\text { San José } \\
\text { (de Aguirre) }\end{array}$ & " \\
\hline 55,30 & San Donato & " \\
\hline 59,45 & Ramírez & “ \\
\hline 63,34 & Constancia & " \\
\hline 68,49 & San Jorge & “ \\
\hline 68,56 & Tres Marías & “ \\
\hline
\end{tabular}

(1) Cuando esté concluido el ramal de esta oficina, el millaje será 39 y el flete de 9,506250 peniques. Fuente: Billinghurst, 1886.

En un sentido inverso, es decir, de sur a norte, el mismo troncal partía desde el puerto de Iquique. Su recorrido comenzaba faldeando los cerros hacia el norte de la ciudad formando un ángulo, siguiendo después al sur hasta el Alto del Molle, donde partía al norte hasta Tres Marías (Cuadro $N^{\circ} 4$ ).
Cuadro $\mathrm{N}^{\circ} 3$

Estaciones recorridas de Pisagua a salitrera Tres Marías

\begin{tabular}{|l|c|c|}
\hline \multirow{2}{*}{ Estaciones } & \multicolumn{2}{|c|}{ Distancia (millas) } \\
\cline { 2 - 3 } & Parciales & Totales \\
\hline Pisagua & 0 & 0 \\
Hospicio & 7 & 7 \\
Arenal & 4 & 11 \\
San Roberto & 5 & 16 \\
Nivel & 2 & 18 \\
Jazpampa & 6 & 24 \\
Zapiga & 5 & 29 \\
Dolores & 2 & 31 \\
San Francisco & 2 & 33 \\
Porvenir & 1 & 34 \\
Camiña & 1 & 35 \\
Santa Catalina & 1 & 36 \\
Aurora & 9 & 45 \\
Abra de Ugarte & 1 & 50 \\
Abra de Quiroga & 2 & 52 \\
Tres Marías & 4 & 56 \\
\hline
\end{tabular}

Fuente: Espinoza, 1897.

A este recorrido se debe considerar una bifurcación en la milla 29, donde estaba la estación central, punto donde partía un ramal hacia el sur llegando a la oficina La Noria, dividiéndose en otros ramales para comunicar diversas salitreras del cantón principal.

Otras líneas de menor importancia recorrían el desierto para que los carros planos pudiesen transportar el mineral. Principalmente destacaba la línea que exportaba por el puerto de Junín, la que recorrería $35 \mathrm{~km}$ y su principal característica era que desde el Alto de Junín existía un andarivel de 1.250 $m$ de longitud, con una altura de 650 m.s.n.m., el que bajaba a la pequeña planicie litoral que existe en ese lugar, donde se encontraba habilitado un embarcadero de salitre (Espinoza, 1897).

Aprovechaban estas líneas las siguientes oficinas: Carolina, Santa Rita, Unión, San Patricio, San Francisco, San Antonio, Cruz de Zapiga, Patria, Reducto, Bearnes, Compañía, entre otras (Figura $N^{\circ} 2$ ). 
Cuadro $\mathrm{N}^{\circ} 4$

Estaciones recorridas de Iquique a salitrera Tres Marías

\begin{tabular}{|l|c|c|}
\hline \multirow{2}{*}{ Estaciones } & \multicolumn{2}{|c|}{ Distancia (millas) } \\
\cline { 2 - 3 } & Parciales & Totales \\
\hline Iquique & 0 & 0 \\
Alto del Molle & 9 & 9 \\
Santa Rosa & 7 & 16 \\
Las Carpas & 4 & 20 \\
San Juan & 3 & 23 \\
La Central & 6 & 29 \\
Laura & 2 & 31 \\
Montevideo & 6 & 37 \\
Pozo Almonte & 6 & 43 \\
Independencia & 2 & 45 \\
La Peña Chica & 4 & 49 \\
La Peña Grande & 2 & 51 \\
San Donato & 4 & 55 \\
Ramírez & 4 & 59 \\
Huara & 5 & 64 \\
San Jorge & 3 & 67 \\
Tres Marías & $11 / 2$ & 68 \\
\hline
\end{tabular}

Fuente: Espinoza, 1897.
Otro lugar de exportación en la costa pacífica de Tarapacá era la localidad de Caleta Buena, la que se conectaba principalmente con la salitrera de Agua Santa. Esta línea recorría $39 \mathrm{~km}$, comunicando a Caleta Buena con Agua Santa y realizando el servicio a las oficinas Rosario de Huara, Mercedes, Progreso, Amelia, Aurora, Democracia, Rosario de Negreiros, Putunchara, Constancia, entre otras. También era posible que se acoplaran a este ramal las oficinas Jazpampa, Primitiva, Paccha, Aguada, Ángela, Sacramento, San Jorge y Tres Marías (Figura No 2).

Para 1897, existió un proyecto para la construcción de un ferrocarril entre Huara e Iquique. Esta línea podría ser el servicio de las siguientes oficinas, entre otras: Buen Retiro, Ramírez, Cala-Cala, La Palma, Peña Chica, San Donato, San Jorge, Santa Rosa de Huara. Lo que se intentaba era conectar el floreciente pueblo de Huara con el puerto de Iquique.

Pasando a otro punto, Huara atraía no solo a los capitales ferroviarios, sino que también a diferentes pobladores que deseaban residir en las inmediaciones de este pueblo-estación. La idea de construir a un costado de las líneas férreas como práctica social para cimentar espacios de convivencia continuó hacia comienzos del siglo XX, como es posible advertirlo en la documentación:

Figura $\mathrm{N}^{\circ} 2$

Distribución de oficinas y conexiones ferroviarias, fines del siglo XIX

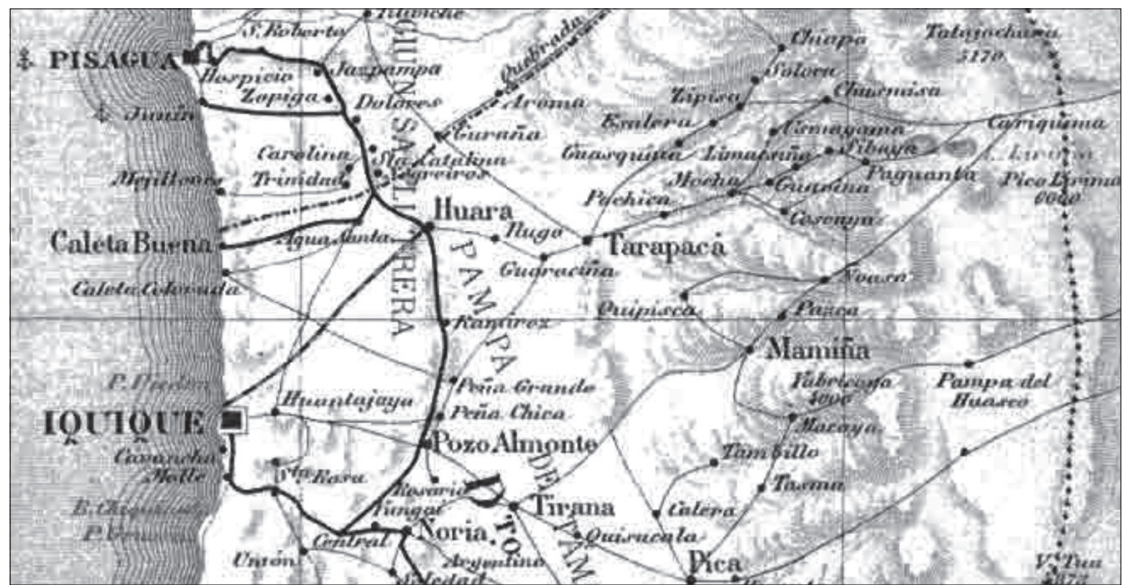

Fuente: Espinoza, 1897. 
"Iquique, febrero 10 de 1904

Señor intendente:

El señor Silvestre Palacios, solicita que se le conceda en arrendamiento un terreno fiscal ubicado en pueblo de Huara, terreno que mide cuarenta metros de frente, por treinta de fondo y lo solicita para construir habitaciones.

En atención al lugar que ocupan los terrenos solicitados, entre las líneas de los dos ferrocarriles, y distante a la vez del pueblo de Huara, nos es posible que acceda a esta solicitud.

Entre las dos líneas férreas no se debe hacer concesión alguna de arrendamiento, a causa de las dificultades que se presentarían a esas líneas para su explotación, como por los peligros que ofrecería a los habitantes de casas que se construyeran.

Estando por otra parte distante del pueblo de Huara haría mas difícil la vijilancia y acción de la policía, siempre escasa en ese pueblo" (AIT, 1904).
Se constata en la anterior solicitud de arrendamiento, que no es cualquier terreno al que se desea acceder, sino un retazo adyacente a la línea férrea, es decir, un lugar predilecto para encontrar pasajeros en busca de alojamiento, como obreros, comerciantes o arrieros. La negativa de la autoridad para entregar este tipo de concesiones apunta a la seguridad, debido a los peligros a los que se expondrían los posibles inquilinos, y asimismo, la lejanía del lugar permitiría que comerciantes, ociosos, prostitutas, borrachos, entre otros, estuviesen alejados de la vigilancia y castigo de la autoridad, que el perímetro del pueblo podía dar.

Al mismo tiempo, pero en otro plano histórico, el establecimiento de Huara trajo consigo que una tradicional ruta se vinculara con las redes ferroviarias (Figuras $\mathrm{N}^{\circ} 3 \mathrm{y}$ $N^{\circ} 4$ ), como lo fueron los senderos y caminos troperos de arrieros y agricultores que influenciados por la actividad salitrera reorientaron sus producciones para abastecer de alfalfa, frutas, verduras, carne, charqui, pan y también mano de obra a las oficinas.

A Huara llegaron arrieros a posadas o "tambos" (Figuras $\mathrm{N}^{0} 5$ y $\mathrm{N}^{\circ} 6$ ) para refugiar-

Figura $\mathrm{N}^{\circ} 3$

Estación del ferrocarril, Huara, inicios del siglo XX

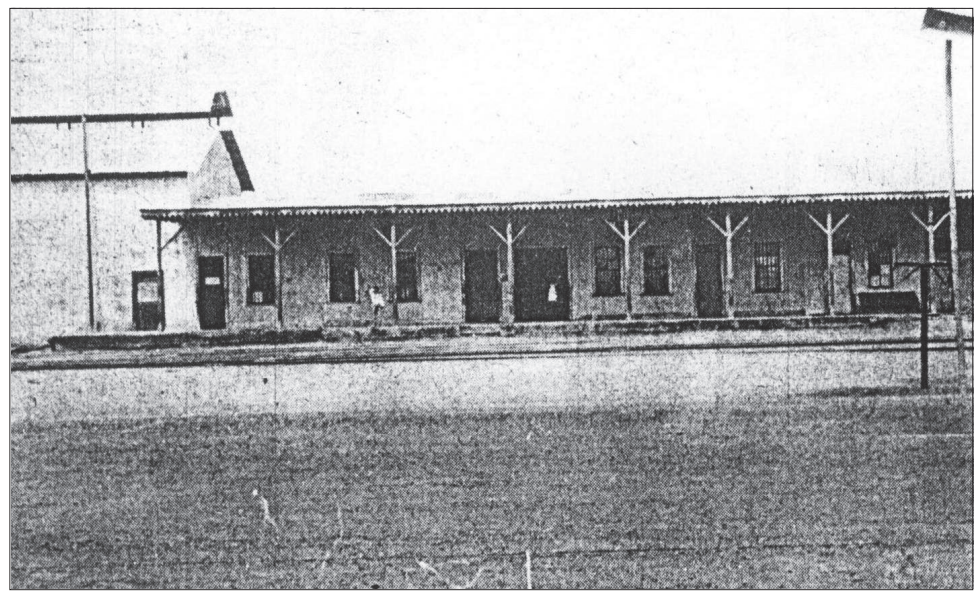

Fuente: Colección personal de los autores. 
se, alimentar a mulares y camélidos y guarecerlos en corrales, expendiendo los productos que traían desde los valles y altiplanicies a comerciantes locales en la calle Arturo
Prat o como ambulantes en el sector de la estación del ferrocarril salitrero, vendiendo frutas y otras especies a los pasajeros (Figura $\left.N^{\circ} 7\right)$.

Figura $\mathrm{N}^{\circ} 4$

Estación del ferrocarril, Huara, alrededor de 1920

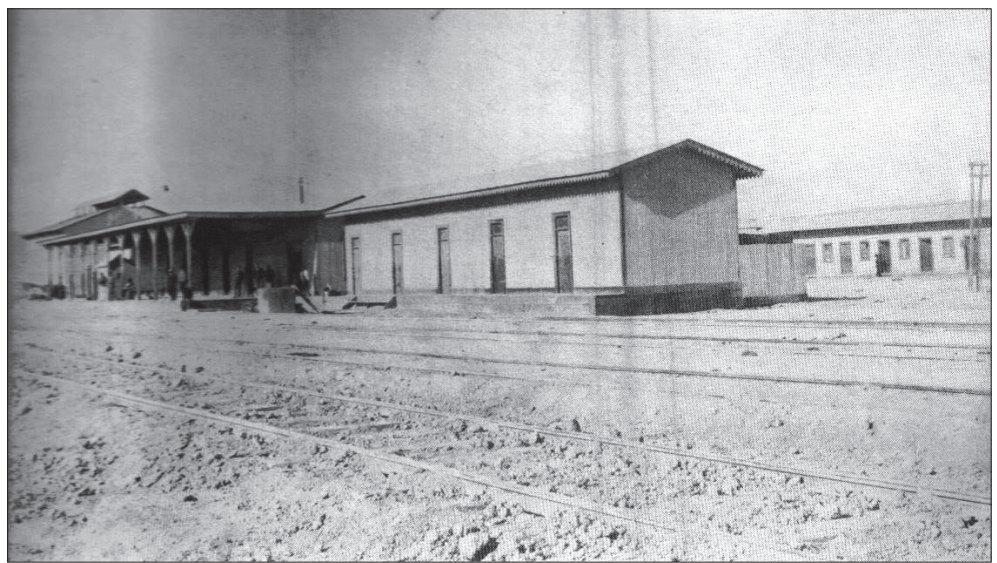

Fuente: Colección personal de los autores.

Figura $\mathrm{N}^{\circ} 5$

Ubicación de antiguos tambos insertos en la trama urbana

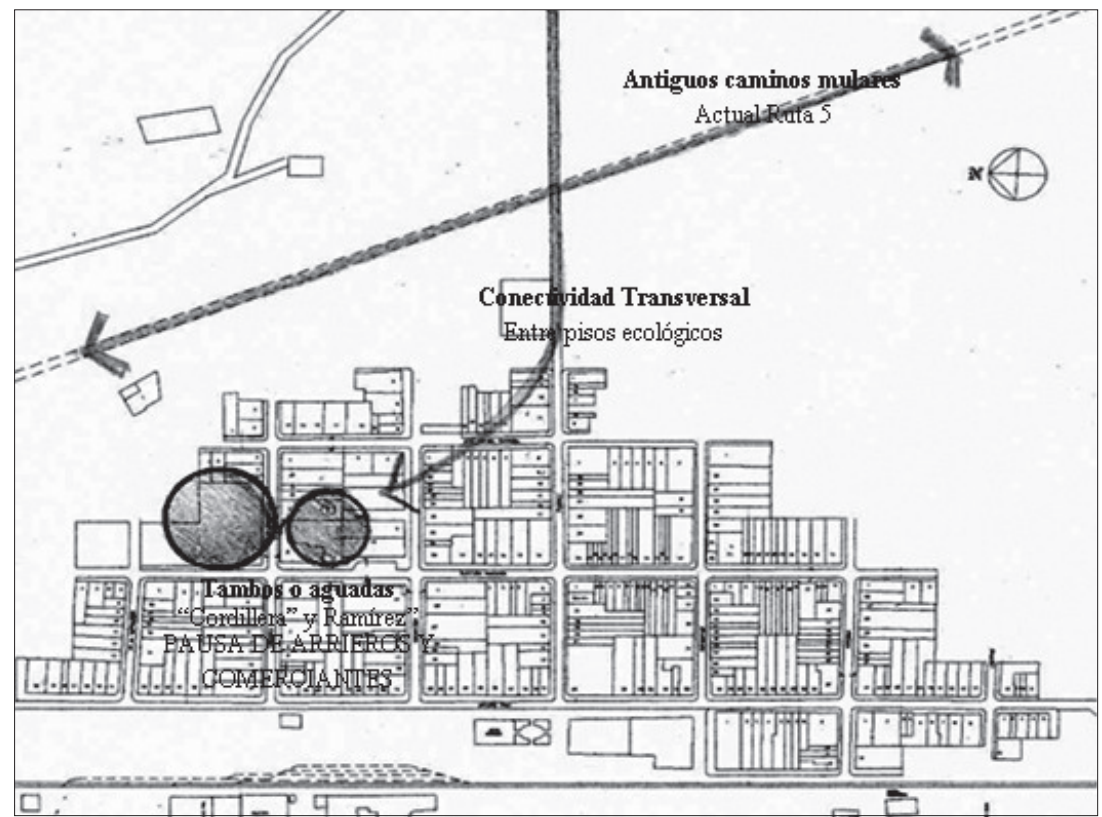

Fuente: Esquivel, Sepúlveda y Toledo, 2005. 
Al escudriñar el pasado del pueblo, es imperioso una aproximación a las formas de vida de los que habitaron esta localidad; sus representaciones en el espacio que residie- ron y cómo van cargando con sentido cada centímetro de los lugares en los cuales se desenvuelven en su quehacer cotidiano, ya sea al alero del ferrocarril pampino, como

Figura $\mathrm{N}^{\circ} 6$

Tambo "San Juan", década de 1920

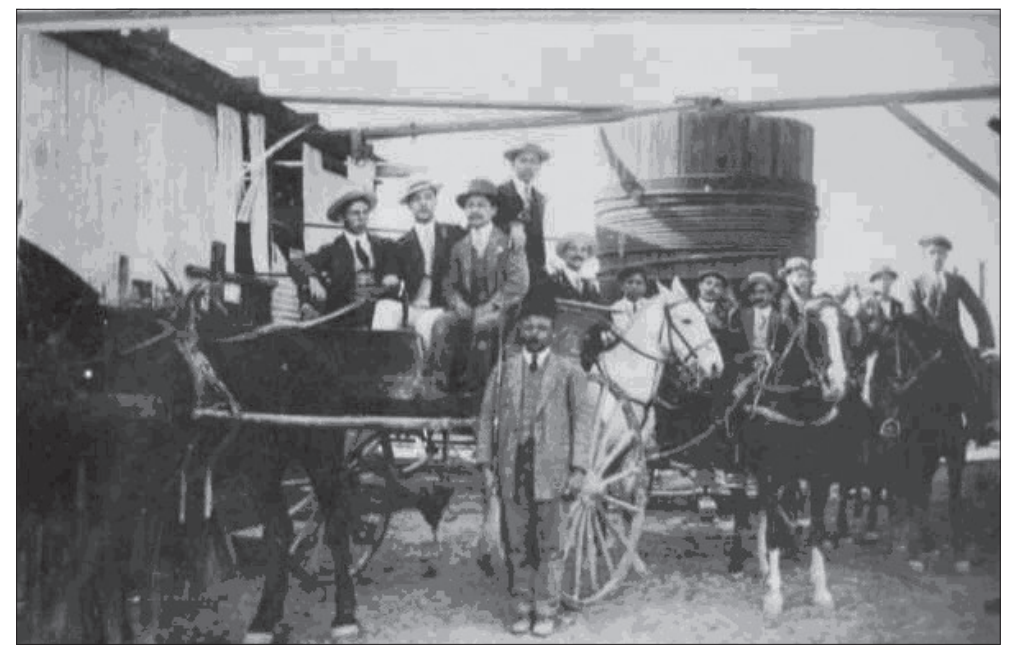

Fuente: Colección personal de los autores.

Figura $\mathrm{N}^{\circ} 7$

Plano de Huara hacia 1920

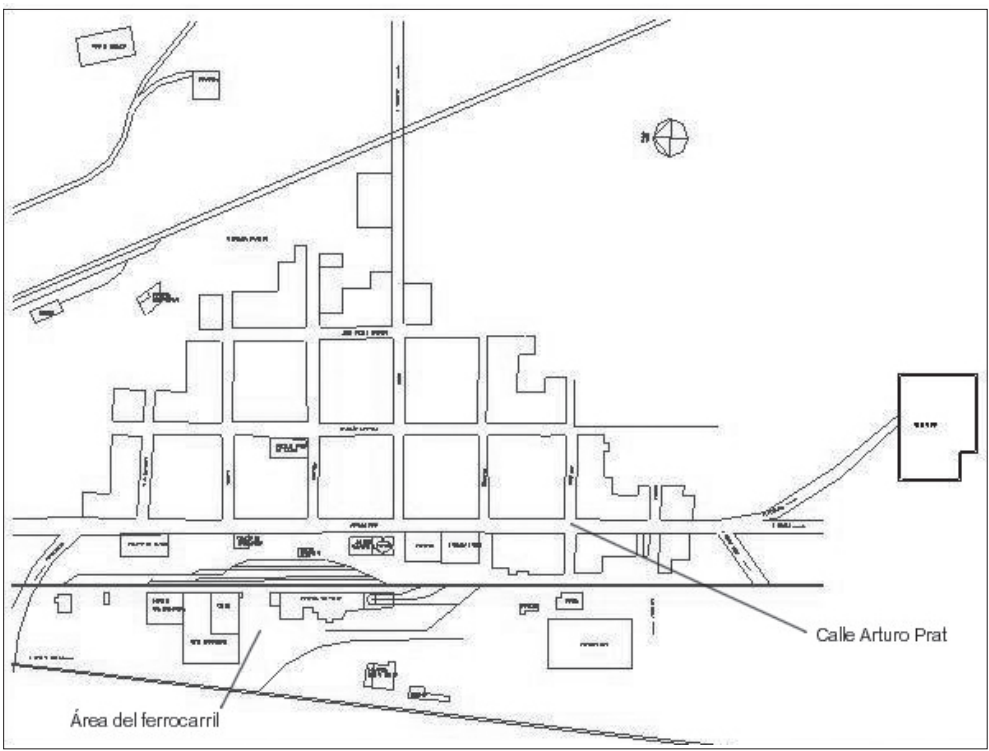

Fuente: Esquivel, Sepúlveda y Toledo, 2005. 
en la actividad comercial o las redes de mercadeo que Huara fue promoviendo como un asentamiento que dinamizó como vector tanto a obreros, ferroviarios, profesores, comerciantes, arrieros y campesinos de las quebradas adyacentes a la pampa del Tamarugal. A decir de Elizabeth Jelin y Victoria Langland (2003), "lo que intentamos comprender no es solamente la multiplicidad de sentidos que diversos actores otorgan a espacios físicos en función de sus memorias, sino los procesos sociales y políticos a través de los cuales estos actores (o sus antecesores) inscribieron los sentidos en esos espacios, o sea, los procesos que llevan a que un espacio se convierta en un lugar" (Jelin y Langland, 2003: 3).

\section{La percepción y los mapas mentales en la pampa}

"Los lugares que vivimos, y frecuentamos jamás desaparecerán completamente, los dejamos sin dejarlos; ellos viven dentro nuestro, a veces invisibles y a veces presentes, ocultados en nuestra memoria; las imágenes reunidas aquí son la prueba de que debemos redescubrirlos constantemente" (Perec, 2000: 179).

La percepción que tienen los pobladores sobre su entorno está sujeta a los espacios, colores, manifestaciones artísticas y expresiones comunicacionales que conviven en esta. Vale matizar que cada sujeto explica de distinta manera los fenómenos que acontecen en su entorno, pero existen semejanzas al momento de construir un mapa mental del espacio en el cual desarrollan sus actividades.

A partir de esa concepción se ha llegado a hablar de los "imaginarios urbanos". Esta categoría de análisis se refiere a la asociación que hacen los lugareños de las locaciones de su entorno, es decir, la importancia que tienen los lugares, como por ejemplo: los centros comerciales, el casco antiguo, las avenidas más transitadas, las edificaciones cargadas de historia, los puntos de encuentro para personas de distinto sexo, género, edad y condición socioeconómica. Bajo estos parámetros, los protagonistas de la vida urbana relacionan los lugares de acuerdo a sus características y a lo que estas comunican al instante. Baudrillard (1981) habla de colores, muebles y edificaciones cálidas y frías cuando explica el grado de sensibilidad que perciben los sujetos por determinadas cosas. Hace referencia a objetos cargados de historia e identidad, denominándolos cálidos; mientras que Ilama fríos a los que se producen en serie por la lógica del mercado. En otras palabras, lo ligero, desechable y de moda.

Una reflexión similar propuso el antropólogo Marc Augé (2002), al señalar una serie de explicaciones para entender el tránsito y ocupación de los espacios. Denominó como "no lugares" a los "espacios que no poseen identidad, no tienen relación con localismos, sitios característicos y reconocibles o referencias históricas o temporales, no son registrados como lugares memorables por la memoria colectiva, son algo visto pero no registrado" (Augé, 2002: 57). Así se logra entender que los lugares son los espacios en los cuales la persona se reconoce, otorgándole a la vez sentidos, debido a que poseen una carga histórica que los identifica, quedando como parte de la memoria de las relaciones que ellos establecen como colectivo.

Para Bachelard (1992), el "hábitat, la casa y los lugares donde uno vive son impresiones generales de algo simbólico, donde la razón y las sensaciones operan juntas" (Bachelard, 1992: 214); entonces, el lugar está ligado a una situación concreta, pero también a actitudes y a diversas relaciones que mantenemos con los espacios que habitamos y/o circulamos, siendo modificados para su diario vivir. En cierto modo, algunas notas periodísticas ilustran lo anterior:

"Es indudable que el nuevo jefe comunal visitará pronto Huara; sería muy oportuno pedirle en esa visita que consiguiendo con el F. C. Salitrero el permiso necesario para ocupar el terreno de la ex-recoba, hacer trasladar ahí, mejorándolos por cierto, los juegos infantiles que se encuentran en pésimo estado. Esta medida la agradecería la población infantil y embellecería nuestro pueblo" (Diario La Defensa, Huara, 7 de junio de 1935). 
Más adelante se agrega:

"Este paseo es nuestro orgullo, sin embargo en muchas partes centrales la tierra la está cubriendo. Hace falta recoger esa tierra y hoy que el agua salada es baratísima, hacerla regar siquiera una vez a la semana. Pedir esto y ser atendido, ¿sería más fructífero pedir peras al olmo?" (Diario La Defensa, Huara, 7 de junio de 1935).

Las anteriores citas describen cómo los espacios de convivencia se tornan significativos del quehacer cotidiano de la población. Las avenidas donde circulan diariamente los habitantes, las plazas, los juegos infantiles, las estaciones de ferrocarriles, entre otros sitios, son espacios cotidianos a los que los mismos habitantes le dan un sentido de pertenencia, elaborando categorías según la importancia y significación que ellos mismos saben otorgarle. El arreglo de edificios, inmuebles o pintado de fachadas puede ser un recurso utilizado por la autoridad para impregnar cierto compromiso con los intereses del Estado y el orden público, y que paulatinamente se convertirá en compromisos comunitarios en la construcción de espacios:

"Huara, 6 de Septiembre de 1928

En el pueblo de Huara, todos los vecinos han accedido a pintar las fachadas de sus propiedades, en obsequio a 118 Aniversario de Nuestra independencia $\mathrm{Na}$ cional. La escuela $N^{\circ} 28$ de Niñas, propiedad fiscal, se encuentra su fachada exterior bastante en desacuerdo con las propiedades vecinas que la rodean.

En consecuencia, a US. Ruego se digne autorizar se pinte la fachada exterior de este establecimiento que con 15 a 20 tarros de pintura, de 25 libras quedaría hermoseado el edificio en referencia.

Saluda mui atte a US" (AIT, 1928).

Sobre esto, De Certeau (1990) plantea que los lugares son "un cruce de elementos en movimiento: los caminantes son los que transforman en espacio la calle geométricamente, definida como lugar por el urbanis- mo. A este paralelo entre el lugar como conjunto de elementos que coexisten en un cierto orden y el espacio como animación de estos lugares por el desplazamiento de un elemento móvil le corresponden varias referencias que los mismos tiempos precisan" (De Certeau, 1990: 164).

En definitiva, son los seres humanos (lugar antropológico) los que asignan el sentido al lugar. Cada persona se reconoce en el idioma del otro incluyendo sus silencios. En otros términos, el lugar antropológico sería un universo de reconocimiento en el que cada uno sabe cuál es su sitio y el de los demás, así como también distingue los puntos de referencia espaciales, sociales e históricos que comparte con sus pares, pese a diversas situaciones.

\section{Huara como lugar o el lugar de Huara}

En una transecta de larga duración, los sujetos (los huarinos en este caso) le dan vida al lugar como "espacios vividos"; espacios con sentido inscritos o simbolizados, transformando los lugares en espacios o los espacios en lugares según sea la calificación que se les puede otorgar. De esta manera, "los procesos sociales involucrados en 'marcar' espacios implican siempre la presencia de emprendedores de memoria de sujetos activos en un escenario político del presente, que ligan en su accionar el pasado (rendir homenaje a víctimas) y el futuro (transmitir mensajes a las nuevas generaciones)" (Jelin y Langland, 2003: 4).

Los lugares manifiestan experiencias vividas con significados similares. Hacen posible la comunicación entre prácticas sociales desiguales, orientando las acciones de los individuos; buscan regular el uso y apropiación del territorio de manera legítima. El sentido que los individuos le otorgan a un lugar está dado por las representaciones que le atribuyen a esos espacios, es decir, por las imágenes, atributos, significados y usos determinados por la cultura.

Por lo tanto, se puede esbozar la idea de que el espacio es fundamentalmente social, siendo construido a través de la 
participación que hacen de él los individuos mediante prácticas sociales específicas. En definitiva, se intenta comprender la vida cotidiana a partir de aquellas formas de sociabilidad que crean y dan forma al lugar.

\section{Consideraciones finales}

“El espacio captado por la imaginación no puede seguir siendo el espacio indiferente entregado a la medida del geómetra. Es Vivido. $Y$ es vivido, no en su positividad, sino con todas las parcialidades de la Imaginación" (Bachelard, 1992: 175)

El concepto de espacio es definido y utilizado por diversas disciplinas y en distintos contextos. Desde una connotación convencional, ha sido comprendido como un "algo" que contiene objetos, como un soporte de la naturaleza física sobre la que el hombre interactúa. También desde el sentido común, el espacio es tomado como un hecho de la naturaleza, como si fuera una característica objetiva de las cosas, medible y cuantificable (Harvey, 1990). Al hablar de espacio, estamos haciendo referencia a algo que se produce, que es creado. No es algo que exista anteriormente o algo natural; en tanto, es una construcción humana. Lo interesante que se puede plantear es que el espacio social es un correlato en el espacio físico, es decir, se puede ver la posición de los agentes sociales en el lugar que ocupan en el espacio físico (Jelin y Langland, 2003).

Partiendo de la base de que el espacio debe ser leído más allá de sus características físicas y que se presenta como un texto en el cual podemos leer lo que sucede en la estructura social, es fundamental considerarlo como algo que está en constante construcción, significación y resignificación en la medida que las posiciones diferenciales de los sujetos se van transformando, considerando los distintos agentes que en él intervienen.

El uso que se hace del concepto de espacio tiene más relación con el concepto de lugar antropológico que plantea Augé (2002), en tanto está asociado con la historia, la identidad y se sustenta básicamente en las relaciones sociales que se dan en su interior, que son las tres características que el autor le atribuye a este concepto. Augé (2002) retoma la dicotomía lugar/no lugar y, posteriormente, realiza una nueva reflexión, en tanto que muchos espacios que podían ser considerados como no lugares se transforman en lugares para las personas que los usan cotidianamente. Del mismo modo, aquellos lugares se pueden trasformar en no lugares en la medida que las relaciones sociales, la identidad y la historia que los conforman se vayan debilitando.

De acuerdo a estas ideas, son las calles o esos lugares de sociabilidad donde el huarino, ya sea de origen chino, austriaco, italiano, chileno, peruano o boliviano, construye la percepción de sí mismo en las plazas, la iglesia, las calles principales, los sitios de ocio o de diversión. Su propio hogar es para él significativo, ya que en ellos están impregnadas su historia o las historias de sus pares, como en el negocio de la esquina, la panadería, la botica, entre otros. Es el espacio vivido tanto real como imaginado.

Pasando a otro punto, el terremoto de 2005 dejó en evidencia no solo las precarias condiciones en las cuales vivían algunas familias en Huara, sino que de igual forma ha permitido visualizar los grados de compromiso que las familias huarinas de continuidad histórica poseen con el espacio social en Huara, hoy antiguas viviendas que son consideradas por las autoridades y las empresas turísticas como patrimoniales.

La comunidad histórica de Huara se ha conformado a lo largo del tiempo, integrando a nuevos huarinos que han ampliado el universo de componentes sociales ${ }^{7}$. Hay nuevos integrantes de Huara, pero estos son considerados afuerinos, ya que no participan del círculo que encierra socializar o compatibilizar con las huellas del tiempo.

\footnotetext{
7 Como puede ser el caso de ex carabineros que se han quedado viviendo en Huara una vez que pasaron a retiro, y que componen un nuevo segmento, dedicados algunos de ellos a la recolección de materiales dispersos o materiales antiguos como diarios y botellas.
} 
La comunidad de Huara reconoce ciertos edificios como lugares colmados de tradición. Se podría decir que aquellos recintos poseen "marcas o sellos de historicidad", entendiendo la historicidad como la capacidad que poseen los actores sociales de reflexionar y reevaluar su historia, recomponerla, dramatizarla y dinámicamente reconstituirla, impregnando el relato con emociones que surgen al recordar, no importando si ellos fueron testigos o no. La historicidad se reinventa de generación en generación en los lugares que poseen nichos memorísticos o mnemotécnicos del pasado, como verdaderos bolsones o relictos donde se puede aún embriagar de lo remoto, y saciar la sed desértica con epopeyas del ayer (desfiles, fiestas patronales, entre otros).

Evaluando la historia de Huara en cuanto a su conformación, se pueden apreciar tres claros momentos que hipotéticamente grafican el largo siglo XX que ha vivido la comunidad.

Primeramente, está la formación del espacio social de Huara, que se circunscribe al ciclo salitrero. Es el momento donde la población se va asentando, construyendo los sitios y lugares destinados al trabajo, a la recreación, a la venta y a las proclamas políticas. Esta etapa dura hasta 1930 aproximadamente, cuando se inaugura un declive en las actividades laborales que la gente de Huara desarrollaba en torno a la industria salitrera. En teoría, los efectos nocivos para la comunidad se pueden resumir en una migración permanente hacia centros urbanos atractivos económicamente, como Arica y su puerto libre, Iquique y la industria pesquera y minera, Calama y su porvenir minero $u$ otras oficinas que siguieron operando hasta la década del 70, como lo fue Victoria. Pero la gente puede abandonar Huara no solo por motivos económicos; algunos buscarán en los puertos nortinos una amplia gama de oportunidades para continuar los estudios. Es este momento, "el segundo", que metafóricamente hablando, se puede visualizar como el cambio de eje articulador de la sociabilidad en Huara.

Antes, Huara se había constituido como un centro poblado que interactuaba con el ferrocarril. Toda la vida de Huara miraba ha- cia el occidente, ya que las serranías costeras no impedían a la gente disfrutar de un devenir económico auspicioso, aunque con mucho sudor y esfuerzo, en cuanto a la construcción de su comunidad. La vida social giraba en torno a ese escenario, porque un número no menor de población flotante transitaba por las calles polvorientas de Huara, por las líneas de los tres ferrocarriles, tanto para Zapiga o Pozo Almonte, para Iquique o hacia el sur del país, o para la costa hacia Caleta Buena.

De igual forma, el camino fiscal, adyacente a la línea férrea, se localizaba al oeste del pueblo, por lo tanto, la vía moderna por donde circularon los automóviles, entre calaminas y chusca por doquier, fue entre Huara y otros lugares; incluso, hubo carreras de automóviles que desde Buenos Aires venían compitiendo para alcanzar la meta en Caracas, Venezuela, hacia la década de 1940, donde los niños y la juventud de Huara, incluido los curas franciscanos, se agolparon a ver los bólidos, que eran más de 100, pasar raudos frente a ellos, cuando la tarde recién caía.

Pero el tercer momento marca un punto de inflexión. Para 1962 se comienza a construir la Carretera Panamericana (ruta 5 norte), la cual une in extenso infinitos territorios de norte a sur del continente. Para entonces, Huara ya ha sufrido los embates de la migración, pero ahora su eje de sociabilidad se alterará. Ya no será más la calle Arturo Prat (Figuras $N^{\circ} 8$ y $N^{\circ}$ 9) la que dé vida al poblado, o las estaciones de trenes atiborradas de gentío. Ahora son el ruido de los camiones, de camionetas, buses y autos los que llamarán la atención de los huarinos, girando el eje ahora al este, mirando la cordillera andina, volteando a su centro fundante. En definitiva, dando la espalda a los edificios y vías que la vieron nacer y crecer en el pasado.

Actualmente, Huara posee este eje social (Figura $N^{\circ} 10$ ), donde la carretera influyó para que se trasladaran algunos locales que antes estaban en calle Prat, pero ahora miran como posadas la circulación carretera, como es el caso del restaurante La flor de Huara. Hay nuevas viviendas, incluida la tenencia de carabineros, que se puede reco- 
nocer como no lugares, ya que derivan de la administración estatal, con fachadas que alteran significativamente las formas, colores y estilos que en Huara existían. Es por eso que las ruinas, los viejos edificios que aún permanecen indemnes, son lugares cargados de historicidad, que permiten ritualmente, mediante la memoria, conectarse con la gente que ya se marchó, cuando Huara se imponía mirando, paradójicamente, el desarrollo en occidente.

Por ahora, Huara, su comunidad y su pasado es más que un espejismo del desierto.

Figura $\mathrm{N}^{\circ} 8$

Calle Arturo Prat, Huara, 1942

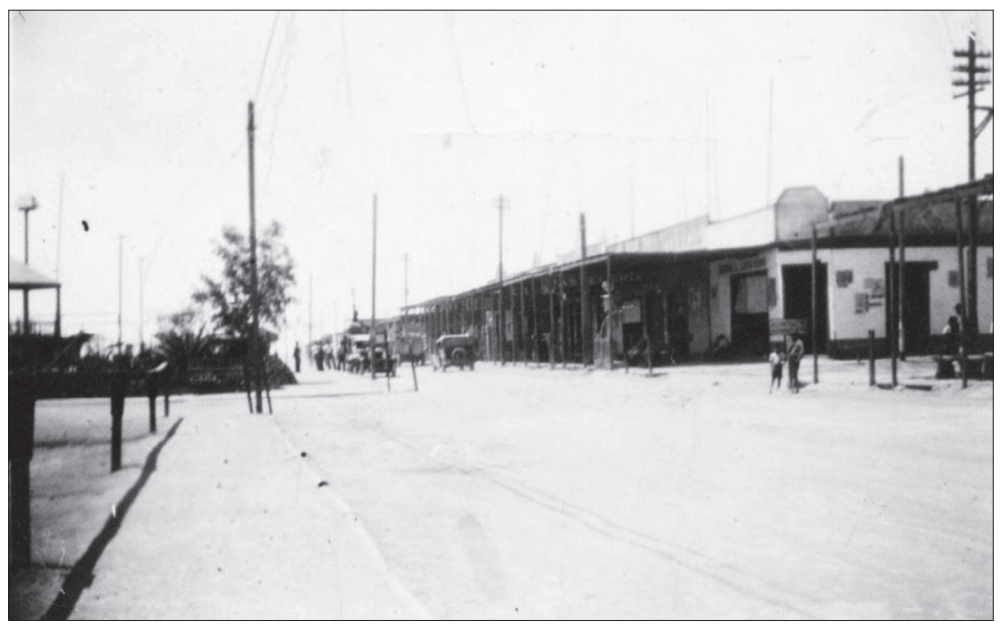

Fuente: Colección personal de los autores.

Figura $N^{\circ} 9$

Calle Arturo Prat, Huara, 2007

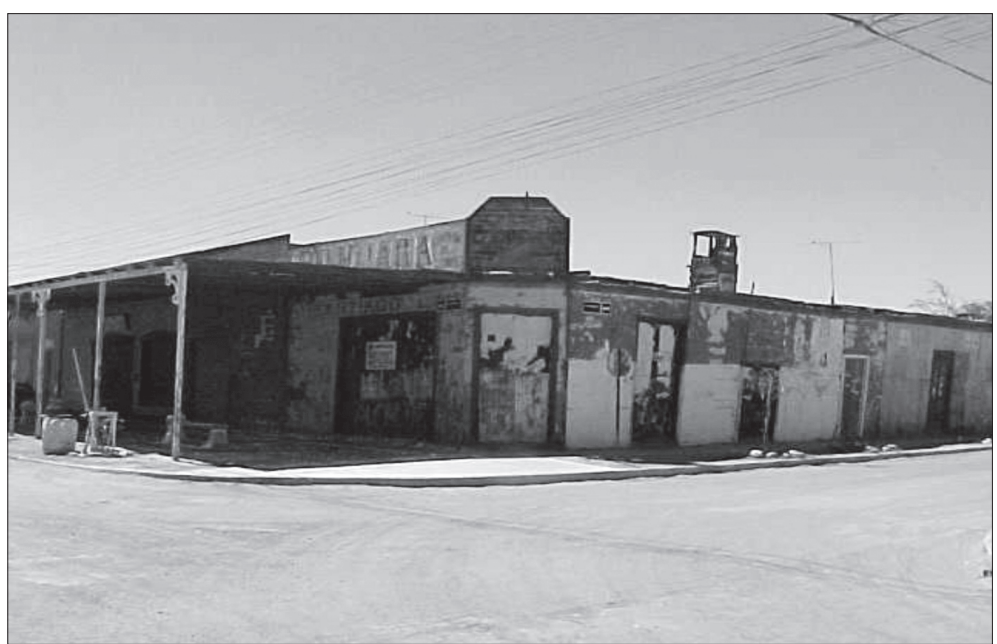

Fuente: Colección personal de los autores. 
Figura $\mathrm{N}^{\circ} 10$

Plano de etapa salitrera y ruta 5, Huara

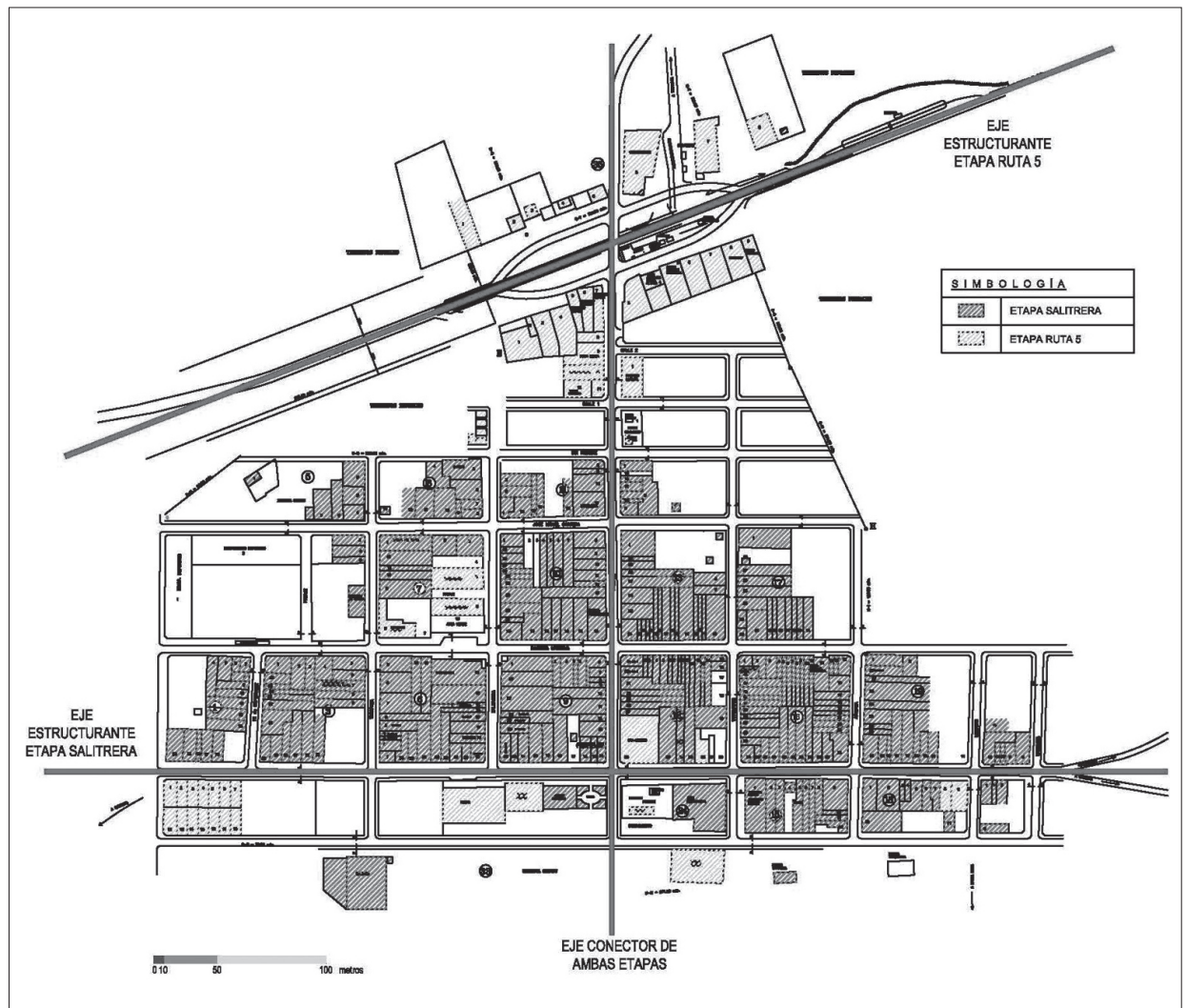

Fuente: Esquivel, Sepúlveda y Toledo, 2005.

\section{Referencias bibliográficas}

ARAVENA, P. Patrimonio, memoria e historicidad: el contenido político de nuestra relación con el pasado. En: GÁLVEZ, M. et al. (comp.). Tarapacá, un desierto de historias. Historia, cultura y memoria en el norte chileno, siglos $X I X$ y $X X$. Iquique: Taller de Investigaciones Culturales, Universidad de Tarapacá, 2003, p. 163-174.

ARAVENA, P.; CATALDO, B.; CONTRERAS, N. y VILLANUEVA, A. Trabajo, memoria y experiencia. Fuentes para la historia de la modernización del puerto de Valparaíso. Valparaíso: Universidad ARCIS, Consejo de la Cultura y las Artes, y CEIP, 2006.
ARCHIVO DE LA INTENDENCIA DE TARAPACÁ (AIT). Libro de solicitudes. Vol. 1, No 45. Iquique, AIT, 1904.

ARCHIVO DE LA INTENDENCIA DE TARAPACÁ (AIT). Libro subdelegados. Vol. 28, No 138. Iquique: AIT, 1928.

AUGÉ, M. Los "no lugares" espacios del anonimato. Una antropología de la sobremodernidad. Barcelona: Gedisa Editorial, 2002.

BACHELARD, G. La poesía del espacio. París: Editorial Presses Universitaires de France, 1992.

BAUDRILLARD, J. El sistema de los objetos. Ciudad de México: Siglo XXI, 1981. 
BERMúdEZ, Ó. Estudios de Antonio O’Brien sobre Tarapacá. Cartografía y labores administrativas 1763-1971. Antofagasta: Ediciones Universitarias Antofagasta, Universidad del Norte, 1975.

BILLINGHURST, G. Estudio sobre la geografía de Tarapacá. Santiago: Imprenta El Progreso, 1886.

BLAKEMORE, H. Gobierno chileno y salitre inglés 1886-1896: Balmaceda y North. Santiago: Editorial Andrés Bello, 1977.

BOURDIEU, P. Cuestiones de sociología. Madrid: Ediciones Istmo, 2000.

CHIPANA, C. Hacia un Pachakuti. En: ALBÓ, X. et al. (comp.). La integración Surandina, cinco siglos después. Antofagasta: Centro de Estudios Regionales Andinos Bartolomé de Las Casas, Corporación Norte Grande, Taller de Estudios Andinos, Universidad Católica del Norte, 1996.

DE CERTEAU, M. La invención de lo cotidiano. Tomo I. París: Editorial Gallimard, 1990.

DÍAZ, A. Huara, de ruinas y memorias. Historia, patrimonio y sociabilidad en las arenas del desierto tarapaqueño. Informe técnico, inédito, 2007.

DÍAZ, A. y MONDACA, C. Geografía y geoglifos de la pampa del Tamarugal. Geografía cultural y arte rupestre andino. Tesis Licenciatura en Pedagogía en Historia. Arica: Facultad de Educación y Humanidades, Universidad de Tarapacá, Chile, 1999.

DONOSO, C. El puerto de Iquique en tiempos de administración peruana. Revista Historia, 2003, vol. 36, p. 123-158.

ESPINOZA, E. Geografía descriptiva de la República de Chile. Santiago: Imprenta y encuadernación Barcelona, 1897.

ESQUIVEL, S.; SEPÚLVEDA, A. y TOLEDO, M. Relación hombre-territorio para la comprensión de la imagen urbana integral de un poblado con identidad pampina. Criterios propositivos para el ordenamiento urbano patrimonial en función de la revitalización de la imagen de Huara. Seminario de investigación. Iquique: Escuela de Arquitectura, Universidad Arturo Prat, Chile, 2005.

GONZÁLEZ, S. Hombres y mujeres de la pampa. Tarapacá en el ciclo de expansión del salitre. Iquique: Taller de Estudios Regionales, Ediciones Especiales Camanchaca No 92, 1991.

GONZÁLEZ, S. Chilenizando Tunupa. La escuela pública en el Tarapacá Andino. Santiago: Ediciones Dibam, 2002a.

GONZÁlEZ, S. Hombres y mujeres de la pampa. Tarapacá en el ciclo de expansión del salitre. Santiago: LOM Ediciones, 2002b.

HARVEY, D. La condición de la posmodernidad. Investigación sobre los orígenes del cambio cultural. Buenos Aires: Amorrortu, 1990.

JELIN, E. y LANGLAND, V. Monumentos, memoriales y marcas territoriales. Madrid: Siglo XXI Editores, 2003.

La Defensa. Publicación periódica de Huara, Chile, Periódico, Huara, 1900-1940, 7 de junio 1935, № 339.

LARRAÍN, H. Etnogeografía. En: INSTITUTO GEOGRÁFICO MILITAR. Geografía de Chile. Tomo XVI. Santiago: IGM, 1987.

NúÑEZ, L. La Tirana, del misterio al sacramento. Antofagasta: Departamento de Teología, Universidad del Norte, 1989.

O'BRIEN, A. Reproducción del plano del tenientazgo de Tarapacá. Santiago: Biblioteca Nacional, 1765.

PEREC, G. Especies de espacios. París: Editorial Galilee, 2000.

RISO PATRÓN, F. Diccionario geográfico de las provincias de Tacna y Tarapacá. Iquique: Imprenta de la Industria, 1890. 
SILVA, D. Guía administrativa y comercial de las provincias de Tacna, Tarapacá y Antofagasta. Santiago: Imprenta y encuadernación Chilena, 1913.
SILVA, L. Carta geológica de Chile. Hojas Piragua y Zapiga. I Región. Santiago: Instituto de Investigaciones Geológicas, 1977.

VAN KESSEL, J. Cuando arde el tiempo sagrado. La Paz: Ediciones Hisbol, Bolivia, 1992. 